\title{
PENGEMBANGAN DESAIN DIDAKTIS GEOMETRI BERBANTUAN PERANGKAT LUNAK CABRI3D PADA PEMBELAJARAN MATEMATIKA SMA
}

\section{DEVELOPMENT OF GEOMETRY DIDACTICAL DESIGN ASSISTED BY CABRI3D IN HIGH SCHOOL MATHEMATICS LEARNING}

\author{
Arif Abdul Haqq ${ }^{1^{*}}$ \\ ${ }^{1}$ Tadris Matematika, Fakultas Ilmu Tarbiyah dan Keguruan, IAIN Syekh Nurjati Cirebon, \\ Jl. Gn. Bromo DXI No 137 RT 02 RW 03, 45141, Indonesia \\ *E-mail: mr.haqq@gmail.com \\ Hp: 085659748716
}

\begin{abstract}
ABSTRAK
Penelitian ini dilatarbelakangi oleh sulitnya siswa untuk mempelajari geometri dimensi 3 khususnya pada konsep jarak sehingga dirasa perlu ada media alat peraga maya berupa perangkat lunak Cabri3D. Alat peraga maya ini digunakan sebagai stimulus alternatif desain pembelajaran matematika pada materi geometri dimensi 3 konsep jarak. Desain ini dirancang dengan sangat memperhatikan karakteristik fenomena learning obstacle dan learning trajectory. Penelitian ini dilakukan di SMA Negeri 5 Kota Cirebon terhadap kelas XII sebanyak 93 orang. Metode penelitian yang digunakan adalah penelitian kualitatif dengan Didactical Design Research. Hasil penelitian ini adalah karakter fenomena learning obstacle dan learning trajectory pada materi Geometri Dimensi 3 Konsep Jarak serta analisis situasi didaktis sebagai desain materinya.
\end{abstract}

Kata kunci: Bahan ajar, penalaran spasial, Cabri3D, situasi didaktis

\section{ABSTRACT}

This research is motivated by the difficulty of students to learn the geometry of 3rd dimension, especially on the concept of distance so that it is felt that there is a need for virtual media props in the form of Cabri3D software. This virtual teaching aid is used as an alternative stimulus to the design of mathematics learning in the geometry of the $3^{\text {rd }}$ dimensional concept of distance. This design was designed with great attention to the characteristics of the phenomenon of learning obstacle and learning trajectory. The research was conducted at SMA Negeri 5 Kota Cirebon for class XII as many as 93 people. The research method used is qualitative research with Didactical Design Research. The results of this study are the character of the phenomenon of learning obstacle and learning trajectory on Geometry of $3^{\text {rd }}$ Dimension concepts Distance Concept and didactical situation analysis as the design of the material.

Keywords: Lesson material, spatial reasoning, Cabri3D, didactical situation 


\section{PENDAHULUAN}

Salah satu dalam pembelajaran geometri tiga dimensi (bangun ruang) di sekolah kadang kita masih menggunakan media papan tulis untuk mengilustrasikan sebuah bangun ruang. Menurut [1][3] dunia sekitar secara fisik tidak dapat semuanya dijelaskan hanya dengan dua dimensi Geometri Euclid. Lebih jauh menurut [4] di sana terdapat banyak konsep dan procedur secara matematis yang dapat dijelaskan dengan representasi geometri. Menurutnya geometri cenderung abstrak dan membuat masalah sulit untuk dipahami bagi kebanyakan siswa. Tidak jarang siswa mengalami hambatan dalam memahami maksud yang terdapat dalam konsep maupun prosedur matematika. Dalam keadaan tertentu apa yang disajikan dalam papan tulis itu bisa berbeda sudut pandang.

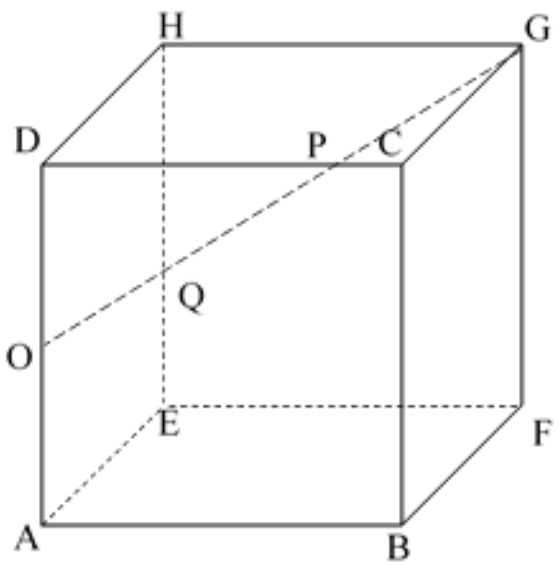

Gambar 1.

\section{Ilustrasi Perbedaan Sudut Pandang Siswa dalam Permasalahan Geometri Dimensi 3}

Berikut ini salah satu contoh perbedaan sudut pandang siswa tentang ilustrasi gambar 1 untuk menjelaskan kedudukan garis GO terhadap kubus $A B C D$.EFGH dengan $O$ berada di tengah rusuk $A D$. Terdapat kemungkinan siswa menganggap bahwa garis $G O$ melalui titik $P$ yang terletak pada rusuk $C D$ dan $Q$ yang terletak pada rusuk EH. Padahal kenyataannya tidak melalui kedua titik tersebut. Perbedaan sudut pandang tersebut tidak akan terjadi jika terdapat alat peraga yang membantu siswa dalam memahami kedudukan tersebut.

Dalam era teknologi informasi, penggunaan perangkat lunak terkait geometri sebagai alat peraga dapat dilakukan guru dalam upaya menyelesaikan masalah dalam pembelajaran matematika. Dalam hal tersebut [4] mengemukakan bahwa integrasi dalam pembelajaran matematika memungkinkan pembelajaran matematika menjadi lebih interaktif. Menurutnya siswa dapat memahami konsep yang diberikan dengan bantuan perangkat lunak, siswa dapat memanipulasi dan memvisualisasikan melalui perangkat lunak.

Salah satu alat peraga berupa perangkat lunak yang terkait geometri tiga dimensi adalah aplikasi Cabri3D. Cabri3D adalah perangkat lunak atau aplikasi komputer yang dapat memberikan gambaran atau visualisasi tiga dimensi di layar komputer. [7] menyatakan bahwa penggunaan perangkat lunak ini membawa inovasi revolusioner ke dalam pembelajaran geometri dan ini adalah langkah yang sangat penting sejak geometri diajarkan oleh Euclid. Visualisasi tiga dimensinya hampir mendekati kenyataan dengan memberi kebebasan kepada pengguna untuk memanipulasi bangun tersebut. Cabri 3D dibuat khusus untuk mengatasi persoalan-persoalan geometri tiga dimensi. Cabri3D ini dapat diperoleh di situs www.cabri.com.

Persoalan-persoalan geometri tersebut akan terurai dengan pengembangan sebuah desain didaktis yang dapat mereduksi hambatan 
belajar atau learning obstacle (LO) siswa dan menduga lintasan belajar atau learning trajectory (LT) dalam mempelajari geometri. Menurut [3] desain didaktis tersebut diharapkan mampu menganalisa kebutuhan siswa dalam pembelajaran dan membantu guru dalam menjawab kebutuhankebutuhan siswanya. Proses mengembangkan sebuah desain didaktis seperti ini, dapat dilakukan dalam suatu kajian yang disebut dengan Didactical Design Research (DDR). Penelitian ini merujuk pada [10] yang mana pada dasarnya penelitian ini terdiri atas tiga tahapan yaitu: (1) analisis situasi didaktis sebelum pembelajaran berupa desain didaktis hipotetik termasuk Antisipasi Didaktis Pedagogis (ADP), (2) analisis metapedadidaktik, dan (3) analisis retrosfektif yakni analisis yang mengaitkan hasil analisis situasi didaktis hipotetik dengan hasil analisis metapedadidaktik. Dari ketiga tahapan ini akan diperoleh desain didaktis empirik yang tidak tertutup kemungkinan untuk terus disempurnakan berdasarkan Teori Situasi Didaktis.

Situasi Didaktis merupakan ungkapan penalaran matematis hubungan antara siswa dan materi pelajaran yang akan dipelajari (Didaktis) [9]. Penalaran matematis sendiri adalah penalaran adalah kemampuan seseorang dalam menarik kesimpulan melalui langkah- langkah formal yang didukung oleh argumen matematis berdasarkan pernyataan yang diketahui benar atau yang telah diasumsikan kebenarannya [2]).

Penalaran spasial adalah proses dimana informasi tentang objek dalam ruang dan hubungan antara keruangan dikumpulkan dengan berbagai cara, seperti pengukuran, observasi, atau inferensi, dan digunakan untuk sampai pada kesimpulan yang valid mengenai hubungan benda-benda atau dalam menentukan bagaimana untuk menyelesaikan masalah tertentu. Penalaran spasial digunakan dalam menyimpulkan semua hubungan spasial. Penalaran spasial merupakan dasar dalam proses mencari solusi sebuah masalah keruangan dari mengenali dan memanipulasi bentuk. [12] menjelaskan bahwa kemampuan penalaran spasial adalah kemampuan untuk memproses dan membentuk ideide melalui hubungan spasial antara objek-objek guna untuk menemukan solusi dari sebuah permasalahan. Kemampuan penalaran spasial sangatlah menginformasikan kemampuan kita untuk menyelidiki dan memecahkan masalah.

Berdasarkan beberapa hasil penelitian-penelitian sebelumnya, ditemukan beberapa penelitian yang ada kemiripan dengan masalah penelitian yang akan diteliti, diantaranya [1][3]. Dalam penelitian ini mengungkapkan adanya peningkatan kemampuan spasial yang signifikan bila diberikan pembelajaran menggunakan Software Dinamis Geometri yang diantaranya menggunakan perangkat lunak Cabri3D. [4] dalam penelitiannya menunjukkan bahwa siswa yang diberikan Model Eliciting Activities dengan Cabri3D memiliki kemampuan penalaran spasial yang lebih baik daripada mereka yang diberi Model Eliciting Activities dengan Cabri 3D. [8] dalam penelitiannya tentang penggunaan perangkat lunak komputer seperti Cabri 3D untuk kegiatan belajar sangat tidak terbatas. [6] dalam penelitiannya berisi mengenai bagai mana guru dapat menggambar secara akurat dan menafsirkan gambar dengan benar, keterampilan keterampilan menggambar siswa dan 
karenanya visualisasi spasial dan orientasi spasial harus dikembangkan. [5] hasil pengamatan peneliti tentang learning obstacle yang dialami siswa ditinjau dari epistemological dan didactical obestacle, bahwa hambatan belajar siswa dalam materi dimensi tiga terletak pada (1) menentukan letak hasil proyeksi suatu titik terhadap garis, (2) menentukan letak hasil proyeksi suatu titik terhadap bidang, dan (3) membuat dan mengenali bentuk sebuah bidang yang memuat titik dan memuat ruas garis pada bidang tersebut (yang memuat hasil proyeksi titik). Penelitian-penelitian tersebut memiliki kemiripan dengan penelitian ini, namun pada penelitian ini dikaji lebih mendalam terkait dengan learning trajectory, antisipasi didaktis pedagogis berdasarkan kemampuan penalaran spasial beserta prediksi responnya. Oleh karenanya penelitian ini akan berfokus pada karakter fenomena learning obstacle dan learning trajectory terkait kemampuan penalaran spasial dalam satu kesatuan desain didaktis serta antisipasi didaktis pedagogisnya.

\section{METODE PENELITIAN}

Jenis penelitian ini adalah menggunakan metode kualitatif deskriptif dengan didactical design research untuk mengatasi hambatan belajar pada materi lingkaran. Terdapat tiga aspek yang diperhatikan dalam alternatif desain pembelajaran ini, yaitu: proses pembelajaran, bahan ajar, dan hambatan belajar [11]. Menurut (Suryadi, 2013) terdapat tiga tahapan yang terdapat pada Gambar 2.

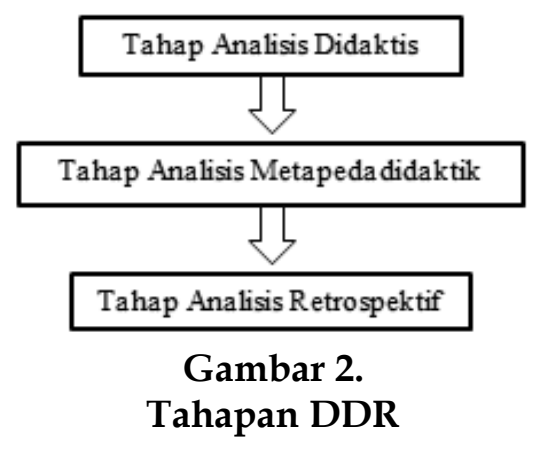

Subjek pada penelitian ini terbagi menjadi dua, yaitu subjek pada uji hambatan belajar dan tes awal kemampuan spasial dan subjek pada implementasi desain didaktis. Subjek untuk mengidentifikasi hambatan belajar dan tes awal kemampuan spasial siswa pada materi geometri dimensi 3 konsep jarak pada kelas XII MIPA 5 (34 orang), dan subjek implementasi dan tes awal kemampuan spasial siswa dari kelas XII MIPA 6 (29 orang) dan XII IPS 2 (30 orang).

Teknik pengumpulan data pada penelitian ini dilakukan dengan melakukan tes uji hambatan belajar dan tes awal kemampuan spasial, wawancara dan studi dokumentasi, sedangkan analisis data pada penelitian ini dilakukan dengan melewati tiga langkah penting yaitu: 1) identifikasi apa yang ada dalam data; 2) melihat pola-pola; dan 3) interpretasi.

\section{HASIL DAN PEMBAHASAN}

Analisis Awal Situasi Didaktis

Bagian Tahap awal penelitian desain didaktis ini adalah analisis situasi didaktis sebelum perlakuan dalam pembelajaran diterapkan. Pada tahap ini dilakukan tes awal untuk mengetahui kemampuan spasial siswa pada materi geometri dimensi 3 konsep jarak pada 93 siswa dari kelas XII MIPA 5 (34 orang), XII MIPA 6 (29 orang) dan XII IPS 2 (30 orang). Tes awal ini terdiri dari 5 butir soal yang terdiri dari soal kontekstual geometri konsep jarak 
sebanyak tiga soal dan soal berbasis Ujian Nasional sebanyak 2 soal. Dengan hasil sebagai berikut:

Pada butir soal nomor 1 siswa diminta untuk menentukan kedudukan antartitik, antargaris dan titik ke garis dalam ruang dengan berbekal konsep titik dan garis yang pernah dipelajari di sekolah menengah pertama.

Pada butir soal nomor 2 siswa diminta untuk menentukan kedudukan titik dalam bidang melalui ilustrasi gambar tentara yang sedang di medan perang dengan menggunakan konsep kedudukan titik pada bidang. Dari permasalahan tersebut siswa juga diminta untuk mencari jarak antar tentara.

Pada butir soal nomor 3 siswa diminta untuj menentukan panjang jarak melalui ilustrasi semut yang hendak memakan gula batu yang berada di atas kotak kayu dengan menggunakan konsep pythagoras dan konsep jarak itu sendiri. Selain itu siswa diminta membuat sketsa ulang jalur tersebut.
Pada butir soal nomor 4 siswa diminta menentukan panjang garis pada bidang dimana bidang tersebut harus dikonstruksi terlebih dulu. Siswa mengkonstruksi gambar kubus kemudian dalam kubus tersebut siswa membuat bidang baru yang diminta sesuai soal. Dalam menjawab pertanyaan ini, siswa menggunakan konsep tata nama dalam kubus dan konsep luas segitiga, serta konsep kesebangunan.

Pada soal nomor 5 siswa diminta menentukan panjang jarak antar dua garis dalam ruang. Siswa mengkonstruksi bangun kubus dengan menggunakan aturan tata nama bangun tersebut dan titik - titik tambahan yang tidak ada pada kubus umumnya. Kemudian dengan menggunakan konsep Pythagoras siswa mencari panjang jarak yang dimaksud.

Berikut adalah hasil dari ketiga kelas setelah mengikuti tes awal:

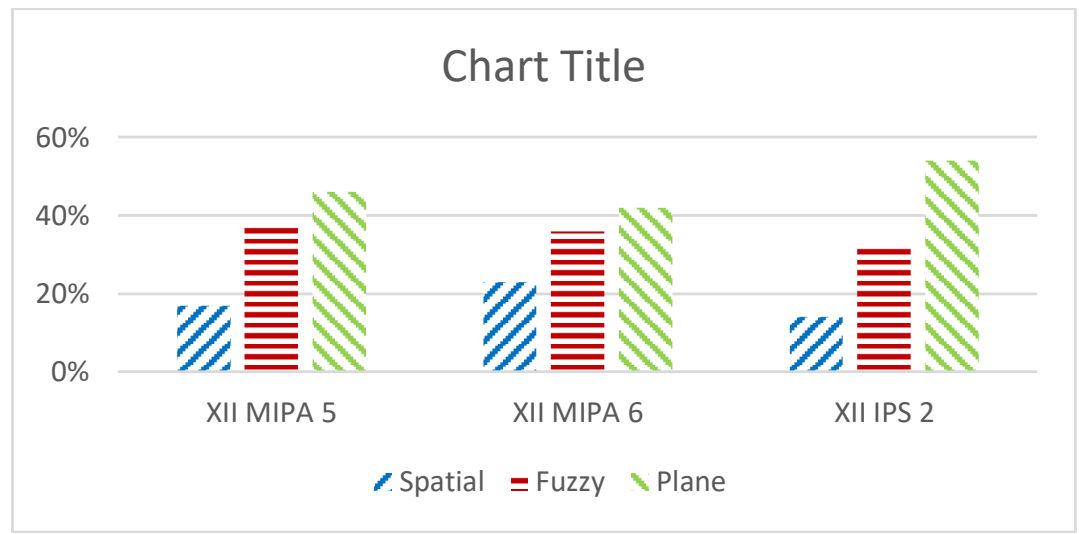

Gambar 3.

Hasil Tes Awal Kemampuan Penalaran Spasial

Tampak pada Gambar 3 ketiga kelas memenuhi model piramida, dimana siswa dengan tingkat penalaran spasial yang memiliki dapat mengkonversi icon dua dimensi menjadi objek tiga dimensi dan dapat membuat hubungan yang benar antara icon dua dimensi dengan objek tiga dimensi. Siswa tersebut dapat menyelesaikan dengan benar disertai penjelasan yang tepat ketika diberikan sebuah permasalahan penalaran spasial. Jumlah siswa dengan tingkat spasial ini paling sedikit di kelas.

Siswa dengan tingkat penalaran Fuzzy yang memiliki kelemahan 
dalam mengkonversi icon dua dimensi menjadi objek tiga dimensi namun dapat membuat hubungan yang benar antara icon dua dimensi dengan objek tiga dimensi. Siswa tersebut dapat menyelesaikan dengan benar tetapi tidak dapat membuat penjelasan dengan tepat ketika diberikan sebuah permasalahan penalaran spasial.

Siswa dengan tingkat penalaran Plane memiliki indikator tidak dapat mengkonversi icon dua dimensi menjadi objek tiga dimensi dan tidak dapat membuat hubungan yang benar antara icon dua dimensi dengan objek tiga dimensi. Siswa tersebut tidak dapat menyelesaikan dengan benar juga tidak dapat memberikan penjelasan dengan tepat ketika diberikan sebuah permasalahan penalaran spasial. Jumlah siswa dengan tingkat spasial ini paling sbanyak di kelas. Dengan demikian, ketiga kelas dapat dieksplorasi situasi didaktisnya karena memiliki proporsi yang sama berdasarkan kemampuan penalaran spasial.

Berdasarkan hasil observasi terhadap 93 siswa dari kelas XII MIPA 5, XII MIPA 6 dan XII IPS 2, berhasil teramati beberapa kesulitan yang termasuk ke dalam epistemological obstacle. Menurut [9][3], dan [11], dan mengungkapkan bahwa hambatan tersebut muncul karena informasi yang diterima siswa untuk menjadi pengetahuan hanya dipahami secara parsial. Siswa hanya memahami konteks-konteks tertentu dalam permasalahan matematika yang dicontohkan saja. Ketika siswa diberi permasalahan matematika konteks yang lain mereka tidak bisa memecahkannya. Siswa mengalami kesulitan dalam mengaplikasikan pengetahuannya dalam memecahkan permasalahan matematika karena ada informasi yang tidak utuh ketika memahami konsep.

Penemuan epistemological obstacle ini didasari oleh penelitian sebelumnya oleh [5] yang menemukan karakteristik epistemological obstacle berupa menentukan letak hasil proyeksi titik pada garis dan pada bidang dan membuat dan mengenali bentuk sebuah bidang yang memuat titik dan memuat ruas garis pada bidang tersebut. Untuk menjaring LO terebut digunakan Lembar Aktivitas Siswa (LAS) Geometri Dimensi 3 Konsep Jarak. LAS tersebut terdiri dari 3 bagian yaitu LAS 1, LAS 2 dan LAS 3. Topik yang dibahas pada LAS 1 mengenai pengertian titik, garis, dan bidang dalam ruang. Topik yang dibahas dalam LAS 2 mengenai jarak antar titik. Topik yang dibahas pada LAS 3 mengenai jarak titik ke garis dan titik ke bidang. Berikut ini dipaparkan hasil temuan epistemological obstacle secara mendetail.

Menentukan Letak Hasil Proyeksi

a. Titik terhadap Garis

Fenomena LO ini terlihat ketika siswa memahami konsep kedudukan titik dan garis dalam ruang. Sebagian besar siswa masih bingung dalam menentukan letak titik pada garis. Menurut hasil wawancara pada beberapa siswa, hal ini disebabkan oleh pemahaman siswa mengenai pengertian titik dan garis serta kedudukannya yang dipahami secara parsial.

b. Titik terhadap Bidang

Fenomena LO ini terlihat ketika siswa memahami konsep kedudukan titik dan bidang dalam ruang. Sebagian besar siswa masih bingung dalam menentukan letak titik pada bidang. Terutama ketika titik itu tidak disertakan dalam gambar. Menurut hasil wawancara pada beberapa siswa, hal ini disebabkan oleh pemahaman 
siswa mengenai pengertian titik dan bidang serta kedudukannya yang dipahami secara parsial dan juga penerapan bahan ajar yang harusnya menggunakan media 3 dimensi, ini hanya menggunakan media 2 dimensi seperti papan tulis dan kertas saja.

Memuat dan mengenali bentuk Sebuah bidang yang memuat titik dan garis pada bidang. Dalam memecahkan masalah jarak tidak menutup kemungkinan untuk menggunakan koneksi dari konsep jarak ke konsep matematika yang lain. Berikut adalah LO yang berhasil teramati ketika konsep jarak dikoneksikan dengan konesp matematika lain.

c. Mencari jarak dengan konsep phytagoras

Siswa kesulitan dalam membuat sketsa dari kamar menjadi bentuk kubus seperti pada soal tersebut di atas. Beberapa siswa kurang tepat menentukan nama tiap titik sudut yang diberikan di soal. Hal ini dikarenakan siswa hanya sebagian memahami konsep pengertian titik, garis, dan bidang dalam ruang. Siswa kesulitan mencari panjang sisi miring dalam suatu segitiga siku-siku yang ada di soal tersebut. Hal ini dikarenakan siswa hanya memahami sebagian konsep teorema Pythagoras.

d. Mencari jarak dengan konsep luas segitiga atau kesebangunan

Siswa masih kebingungan dalam menentukan panjang, lebar dan tinggi pada balok yang ada di soal tersebut. Padahal hal ini merupakan hal dasar dalam geometri dimensi 3 yang sudah dipelajari ketika siswa ada di level sekolah dasar. Selain itu siswa kesulitan menentukan jarak dari titik ke garis yang menggunakan konsep luas segitiga. Siswa hanya memahami sebagian luas segitiga tersebut dengan rumus $\frac{1}{2} \times a \times t$ tanpa memahami kedudukan alas dan tinggi dari suatu segitiga. Siswa hanya memahami alas suatu segitiga adalah yang ada di bagian bawah segitiga dan bagian tinggi segitiga itu yang berdiri tegak lurus (vertikal) dengan bagian alas. Ketika kedudukan alas dan tinggi segitiga diubah, siswa tidak bias memecahkan permasalahan yang diberikan. Dalam menyelesaikan soal ini juga dibuduhkan konesp kesebangunan segitiga. Siswa hanya memahami sebagian saja dari perbandingan dalam konsep kesebangunan segitiga. Akibatnya siswa tidak dapat menentukan persamaan yang tepat dalam mencari jarak.

Setelah mengetahui karakteristik dari fenomena LO pada geometri dimensi 3 konsep jarak hal kemudian yang dilakukan adalah membuat Learning Trajectory (LT) pada geometri dimensi 3 konsep jarak. Tahapan yang dilakukan dalam membuat LT adalah melakukan repersonalisasi materi. Repersonalisasi materi dilakukan dengan mengacu pada empat buku ajar diantaranya: Buku Matematika SMU untuk Kelas 3 Program IPA karya B.K Noormandiri dan Endar Sucipto diterbitkan oleh Erlangga tahun 2000, Matematika Inovatif (Konsep dan Aplikasinya) untuk kelas X SMA dan MA karya Siswanto yang diterbitkan oleh PT Tiga Serangkai tahun 2006, Matematika Kelas X karya dari TIM Kemendikbud Republik Indonesia tahun 2013, dan Matematika kelas XII karya dari TIM Kemendikbud Republik Indonesia tahun 2018.

Proses repersonalisasi materi yang dilakukan adalah proses matematisasi pada geometri dimensi 3 konsep jarak yang dikaitkan dengan konsep matematika lainnya yang telah dipelajari sebelumnya. Pada proses ini dilakukan kajian melalui dua tahap 
sehingga menghasilkan remapping sebagai berikut.

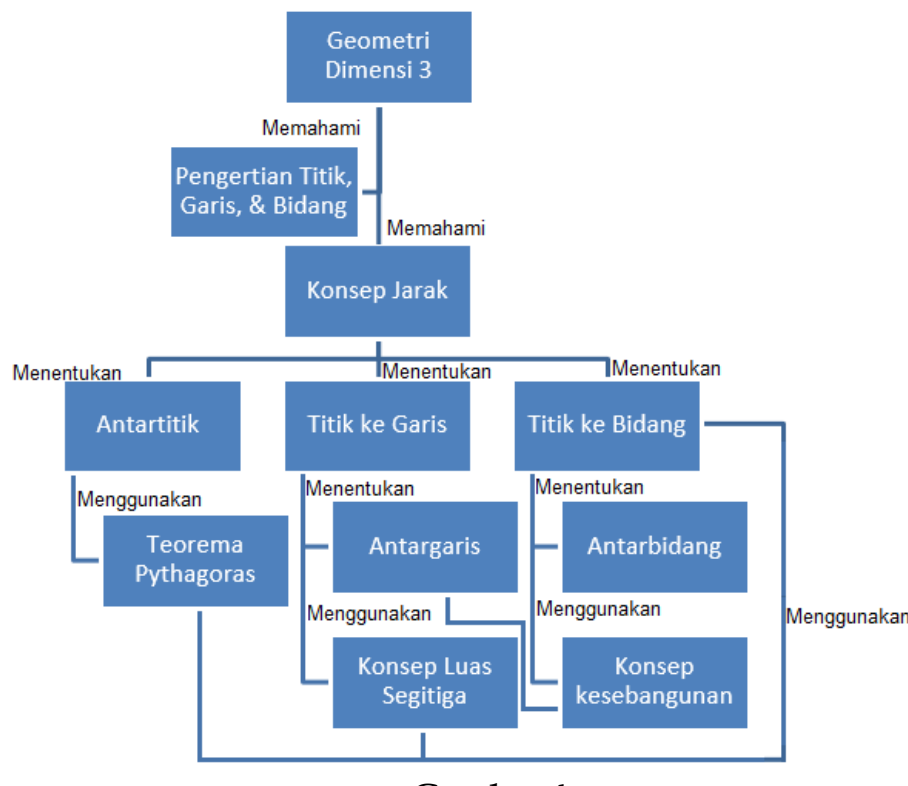

Gambar 4.

Peta Konsep Geometri Dimensi 3 Konsep Jarak

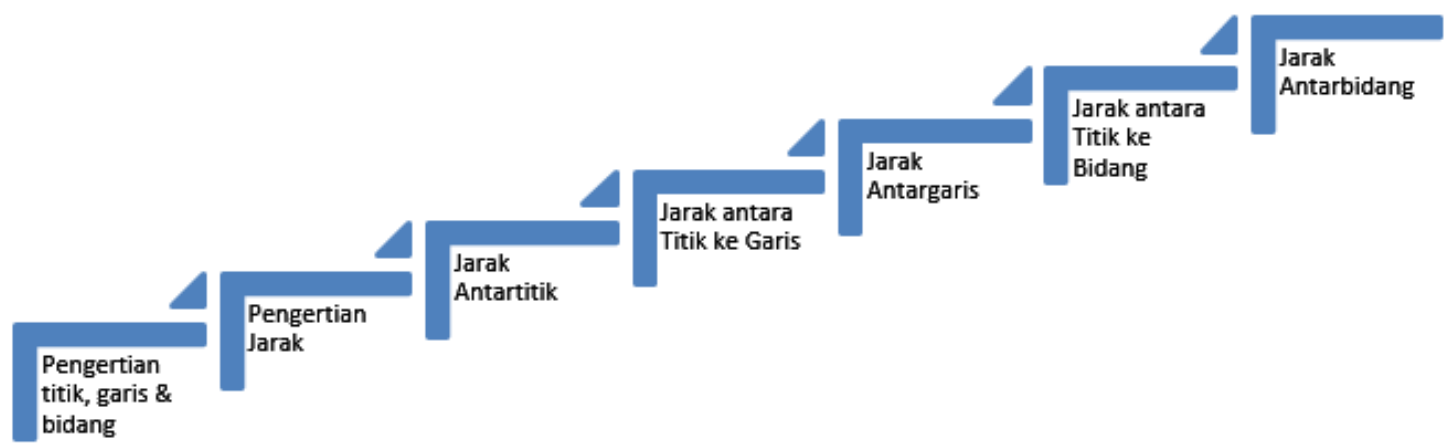

Gambar 5.

Learning Trajectory Geometri Dimensi 3 Konsep Jarak

Secara keseluruhan LT yang dibuat setelah proses repersonalisasi materi tampak seperti pada Gambar 5. Setelah fenomena LO ditemukan dan LT dibuat, kemudian dibuatlah antisipasi situasi didaktis. Antisipasi situasi didaktis ini seperti yang dinyatakan oleh [10] bahwa hasil analisis dari proses tersebut berpotensi menghasilkan desain didaktis inovatif yang dapat diformulasikan sebagai rangkaian langkah untuk menghasilkan desain didaktis baru. Antisipasi ini digunakan untuk mereduksi LO terkait materi Geometri Dimensi 3 konsep jarak. Kemudian disesuaikan dengan LT yang telah disusun untuk disajikan dalam LAS. Berikut disajikan dalam Tabel 1 terkait LO terhadap antisipasi didaktis dan pedagogis sebagai acuan pembuatan situasi didaktis 1 . 
Situasi didaktis 1 ini dibuat untuk mereduksi $L O$ terkait bahkan mengatasinya $100 \%$. LO yang diprediksi Siswa hanya memahami sebagian konsep menentukan letak hasil proyeksi titik terhadap garis. Antisipasi didaktis pedagogis yang dilakukan guru Siswa diarahkan untuk membuat balok pada perangkat lunak Cabri3D untuk mengkonstruksi konsep letak hasil proyeksi titik terhadap garis dan Guru memberikan stimulus berupa clue konstruksi konsep letak hasil proyeksi titik terhadap garis.

Situasi didaktis 2 ini dibuat untuk mereduksi $L O$ terkait bahkan mengatasinya sepenuhnya. $L O$ yang diprediksi Siswa hanya memahami sebagian konsep menentukan letak hasil proyeksi titik terhadap bidang. Antisipasi didaktis pedagogis yang dibuat seperti Siswa dibimbing untuk mempelajari kembali materi menentukan letak hasil proyeksi titik terhadap garis dan diarahkan untuk membuat balok pada perangkat lunak Cabri3D untuk mengkonstruksi konsep letak hasil proyeksi titik terhadap bidang dan Guru membimbing siswa dan memberikan stimulus berupa clue terkait materi letak hasil proyeksi titik terhadap garis agar dapat diterapkan pada materi letak hasil proyeksi titik.

Selanjutnya LO terhadap antisipasi didaktis dan pedagogis sebagai acuan pembuatan situasi didaktis 3. Diprediksi Siswa hanya memahami sebagian konsep mencari jarak antartitik dengan konsep Teorema Pythagoras sedangkan antisipasi didaktis pedagogis yang dilakukan Siswa dibimbing untuk mempelajari kembali materi konsep Teorema Pythagoras dan diarahkan untuk mencari jarak pada perangkat lunak Cabri3D untuk mengkonstruksi konsep jarak antartitik dan Guru membimbing siswa dan memberikan stimulus berupa clue terkait materi Teorema Pythagoras agar dapat diterapkan pada materi konsep jarak antartitik.

Selanjutnya LO terhadap antisipasi didaktis dan pedagogis sebagai acuan pembuatan situasi didaktis 4 sebagai berikut Siswa hanya memahami sebagian konsep mencari jarak titik ke garis dan titik ke bidang dengan konsep konsep luas segitiga atau kesebangunan. Antisipasi didaktis pedagogis yang dilakukan Siswa dibimbing untuk mempelajari kembali materi konsep konsep luas segitiga atau kesebangunan dan diarahkan untuk mencari jarak pada perangkat lunak Cabri3D untuk mengkonstruksi konsep jarak titik ke garis dan titik ke bidang dan Guru membimbing siswa dan memberikan stimulus berupa clue terkait materi konsep luas segitiga atau kesebangunan agar dapat diterapkan pada materi konsep jarak titik ke garis.

Menurut [13] kemampuan penalaran spasial dikategorikan menjadi tiga tingkat yaitu tingkat tinggi (spatial), tingkat sedang (fuzzy), dan tingkat rendah (plane). Berikut indikator dari masing-masing tingkat penalaran spasial. 


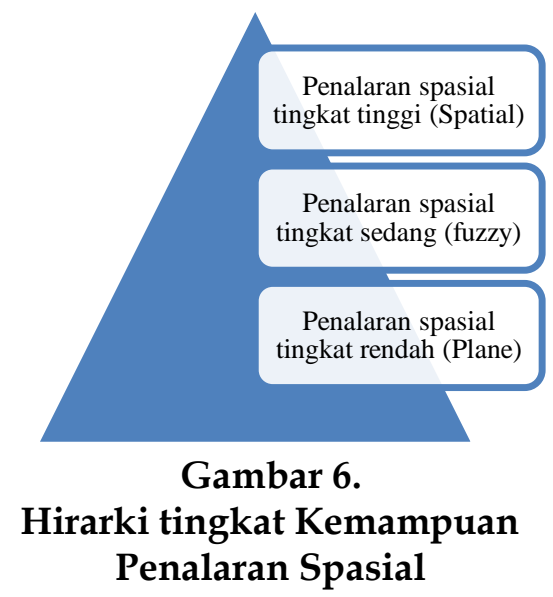

Berikut adalah prediksi respon siswa setelah situasi didaktis dibuat: Siswa yang memiliki kemampuan penalaran spasial tingkat tinggi (spasial) memiliki indikator dapat mengkonversi gambar (icon) dua dimensi menjadi objek tiga dimensi, yaitu anak dapat membuat hubungan yang benar antara gambar (icon) dua dimensi dengan objek tiga dimensi sehingga anak dapat menyelesaikan dengan benar disertai penjelasan yang tepat ketika diberikan sebuah permasalahan penalaran spasial. Siswa yang memiliki kemampuan penaralan spasial tingkat sedang (Fuzzy) memiliki indikator lemah dalam mengkonversi gambar (icon) dua dimensi menjadi objek tiga dimensi, yaitu anak dapat membuat hubungan yang benar antara gambar (icon) dua dimensi dengan objek tiga dimensi sehingga anak dapat menyelesaikan dengan benar tetapi tidak dapat membuat penjelasan dengan tepat ketika diberikan sebuah permasalahan penalaran spasial. Siswa yang memiliki kemampuan penalaran tingkat rendah (Plane) memiliki indikator tidak dapat mengkonversi gambar (icon) dua dimensi menjadi objek tiga dimensi, yaitu anak tidak dapat membuat hubungan yang benar antara gambar (icon) dua dimensi dengan objek tiga dimensi sehingga anak tidak dapat menyelesaikan dengan benar juga tidak dapat memberikan penjelasan dengan tepat ketika diberikan sebuah permasalahan penalaran spasial.

\section{KESIMPULAN}

Karakteristik LO yang dialami siswa dalam mempelajari Geometir Dimensi 3 Konsep Jarak diantaranya siswa hanya memahami konsep (1) menentukan letak proyeksi titik terhadap garis, (2) menentukan letak proyeksi titik terhadap bidang, (3) mencari jarak dengan konsep teorema Pythagoras, (4) mencari jarak dengan konsep luas segitiga atau kesebangunan secara parsial.

Learning trajectory siswa dalam mempelajari Geometri Dimensi 3 Konsep Jarak setelah dilakukan beberapa tahap repersonalisasi melalui beberapa buku ajar yaitu, (1) siswa memahami pengertian titik, garis, \& sudut serta kedudukannya dalam ruang, (2) siswa memahami pengertian jarak, (3) Siswa mencari jarak antartitik dengan teorema Pythagoras, (4) Siswa mencari jarak titik ke garis dengan konsep luas segitiga dan teorema Pythagoras, (5) Siswa menerapkan konsep mencari jarak titik ke garis pada konsep mencari jarak antargaris, (6) Siswa mencari jarak titik ke bidang dengan konsep kesebangunan, luas segitiga dan teorema Pythagoras dan (7) siswa menerapkan konsep mencari jarak antara titik ke bidang untuk mencari jarak antarbidang.

Antisipasi Situasi Didaktis Desain materi Geometri Dimensi 3 Konsep Jarak yang dirancang berdasarkan LO dan LT dibagi menjadi 4 situasi didaktis. Situasi didaktis 1 untuk mengatasi LO ketika siswa menentukan letak proyeksi titik terhadap garis, situasi didaktis 2 untuk mengatasi LO ketika siswa menentukan letak proyeksi titik terhadap bidang, situasi 
didaktis 4 untuk mengatasi LO ketika siswa mencari jarak dengan konsep teorema Pythagoras dan situasi didaktis 4 untuk mengatasi LO ketika siswa mencari jarak dengan konsep luas segitiga atau kesebangunan. Antisipasi situasi didaktis tersebut dibuat dengan harapan dapat mereduksi LO yang muncul ketika siswa mempelajari konsep Geometri Dimensi 3 Konsep Jarak dan bahkan mengatasinya secara penuh.

\section{SARAN}

Perlu dilakukan pengkajian lebih lanjut lagi terkait fenomena karakteristik LO, karena setiap situasi didaktis pasti terus akan berkembang. Perlu dilakukan pengembangan desain dengan menggunakan perangkat lunak berbasis android seperti Geogebra yang masih satu jenis dengan Cabri3D.

\section{UCAPAN TERIMA KASIH}

Terima kasih diucapkan kepada Kementerian Agama Republik Indonesia. Penelitian ini didanai oleh DIPA IAIN Syekh Nurjati Cirebon tahun 2019.

\section{DAFTAR PUSTAKA}

[1] [3] Güven, B., \& Kosa, T. (2008). The effect of dynamic geometry software on student mathematics teachers' spatial visualization skills. Turkish Online Journal of Educational Technology. https://files.eric.ed.gov/fulltext/ EJ1102930.pdf

[2] Haqq, A. A. (2017). Implementasi Challenge-Based Learning dalam Upaya Meningkatkan Kemampuan Penalaran Matematis Siswa SMA. Jurnal THEOREMS ( The Original Reasearch of
Matematics), 1(2), 13-23.

[3] Haqq, A. A., Nasihah, D., \& Muchyidin, A. (2018). DESAIN DIDAKTIS MATERI LINGKARAN PADA MADRASAH TSANAWIYAH. Eduma: Mathematics Education Learning and Teaching. https://doi.org/10.24235/eduma. v7i1.2731

[4] Hartatiana, Darhim, \& Nurlaelah, E. (2017). Student's Spatial Reasoning through Model Eliciting Activities with Cabri 3D. Journal of Physics: Conference Series. https:/ / doi.org/10.1088/17426596/895/1/012075

[5] Hermanto, R., \& Santika, S. (2017). Hypothetical Learning Trajectory Pada Pembelajaran Konsep Jarak. 3(2), 115-128.

[6] Kepceoğlu, İ. (2018). Effect of Dynamic Geometry Software on 3Dimensional Geometric Shape Drawing Skills. Journal of Education and Training Studies, 6(10), 98. https://doi.org/10.11114/jets.v6i1 0.3197

[7] Kösa, T., \& Karakuş, F. (2010). Using dynamic geometry software Cabri 3D for teaching analytic geometry. Procedia - Social and Behavioral Sciences, 2(2), 1385-1389. https://doi.org/10.1016/j.sbspro. 2010.03.204

[8] Priatna, N. (2017). Students' Spatial Ability through Open-Ended Approach Aided by Cabri 3D. Journal of Physics: Conference Series, 895, 012065.

https://doi.org/10.1088/17426596/895/1/012065

[9] Sulistiawati, S., Suryadi, D., \& Fatimah, S. (2015). Desain Didaktis Penalaran Matematis untuk Mengatasi Kesulitan Belajar Siswa SMP pada Luas dan Volume Limas. Kreano, Jurnal Matematika 
Kreatif-Inovatif.

https://doi.org/10.15294/kreano. v6i2.4833

[10] Suryadi, D. (2013). Didactical Design Research ( Ddr ) dalam pengembangan pembelajaran matematika. In Prosiding Seminar Nasional Dan Pendidikan Matematika.

http:/ / www.academia.edu/down load/55599800/SEMNAS-PMAT2013_Jurnal_Didi_Suryadi_DDR.p df\#page $=13$

[11] Haqq, A. A., \& Toheri, T. (2019). Reduksi Hambatan Belajar melalui Desain Didaktis Konsep Transformasi Geometri. SJME (Supremum Journal of Mathematics Education), 3(2), 117127.

[12] Williams, C. B., Gero, J., Lee, Y., \& Paretti, M. (2010). Exploring spatial reasoning ability and design cognition in undergraduate engineering students. Proceedings of the ASME Design Engineering Technical Conference. https://doi.org/10.1115/DETC20 10-28925

[13] Tian, Z., \& Huang, X. (2009). A Study of Children's Spatial Reasoning and Quantitative Reasoning Abilities. Journal of Mathematics Education (C) Education for All, 2(2), 80-93. Retrieved from http://www.educationforatoz.net /images/_9734_7_Zhong_Tian.pd $\mathrm{f}$ 